resection for carcinoma: comparision between the stright and colonic J pouch reconstruction // Br. J. Surg.1996. №83. P. 398-392.

36. Ho Y.H., Yu S., Ang E.S., et al. Small colonic J-pouch improves colonic retention of liquids-randomized, controlled trial with scintigraphy // Dis. Colon Rectum. 2002. Vol. 45, №1. P. 76-82.

37. Lazorthes F., Chiotasso P., Gamagami R.A., et al. Late clinical outcome in a randomized prospective comparison of colonic J pouch and straight coloanal anastomosis // Br. J. Surg. 1997. №10. P. 1449-1451.

38. Pimentel J.M., Duarte A., Gregorio C., et al. Transverse coloplasty pouch and colonic Jpouch for rectal cancer comparative study // Colorectal Dis. 2003. Vol. 5, №5. P. 465-470.
39. Fazio V.W., Zutshi M., Remzi F.H., et al. A randomized multicenter trial to compare long-term functional outcome, quality of life, and complications of surgical procedures for low rectal cancers // Ann. Surg. 2007. Vol. 246, №3. P. 481-490.

40. Baker J.W. Low end to side rectosigmoidal anastomosis; description of technic // Arch. Surg. 1950. Vol. 61, №1. P. 143-157.

41. Будтуев А.С. Анастомоз бок в конец при низких передних резекциях прямой кишки: Дис. ... канд. мед. наук. М.; 2015. Доступно по: http://medical-diss.com/ medicina/anastomoz-bok-v-konets-pri-nizkihperednih-rezektsiyah-pryamoy-kishki. Ссылка активна на 25.11.2017.

Куликов Е.П. - д.м.Н., профессор, зав. кафедрой онкологии с курсом лучевой диагностики ФДПО ФГБОУ ВО РязГМУ Минздрава России, г. Рязань, Российская Федерация. ORCID ID 0000-0003-4926-6646, Researcher ID U-3350-2017.

Каминский Ю.Д. - к.м.н., доцент кафедры онкологии с курсом лучевой диагностики ФДПО ФГБОУ ВО РязГМУ Минздрава России, г. Рязань, Российская Федерация. SPIN 4546-0324, ORCID ID 0000-0001-87853687, Researcher ID U-3096-2017.

Клевцова С.В. - ассистент кафедры онкологии с курсом лучевой диагностики ФДПО ФГБОУ ВО РязГМУ Минздрава России, г. Рязань, Российская Федерация. ORCID 0000-0001-7708-1644, Researcher ID U-3095-2017.

E-mail: klevcovasveta1@rambler.ru

(C) Kulikov E.P., Kaminskiy Y.D., Klevcova S.V., 2017

\title{
SURGICAL CORRECTION OF FUNCTIONAL DISORDERS IN PERFORMING SPHINCTEROSAFING OPERATIONS FOR RECTAL CANCER (literature review)
}

\author{
E.P. Kulikov, Y.D. Kaminskiy, S.V. Klevcova \\ Ryazan State Medical University \\ Vysokovoltnaya str., 9, 390026, Ryazan, Russian Federation
}

For many decades the main goal of oncologists was to increase life expectancy of patients with malignant tumors, without paying due attention to quality of life. Currently, the goals of patients' treatment with rectal cancer are to cure, to minimize the risk of local recurrence, preserve the normal course of intestine, to optimize it's function and to ensure 
quality of life. For a long time, the standard surgical treatment of patients with low rectal cancer was abdominoperineal extirpation, but recently sphincterosafing operations have seen a widespread introduction in surgical practice. However, functional results after these types of operations don't always meet the expectations of surgeons and patients. In the postoperative period, patients often develop a syndrome of low anterior resection, characterized by frequent bowel movements, repeated, prolonged and incomplete evacuation of bowel and the imperative urge to defecate. The manifestation of this syndrome can significantly impair the quality of patient's life and reduce to nothing the efforts of the surgeon to preserve the sphincter of the rectum. For surgical correction of low anterior resection syndrome, various types of colonic reservoir anastomoses have been proposed. The purpose of formation of colonic reservoirs is to increase the cumulative function of intestine. However, the existing methods have several disadvantages related to technical complications and the risk of developing evacuation dysfunction, which is the reason for search the new ways of optimization of anastomoses when performing sphincterotomy operations for cancer of the rectum.

Keywords: colorectal cancer, sphincterosafing operations, low anterior resection syndrome, anastomosis.

Until recently, abdominoperineal extirpation was the primary treatment for patients with tumor in middle and lower thirds of the rectum in colorectal surgery, but lately there is a trend to expand the indications for performing sphincterosafing operations [1]. It has been proven that intramural spread of the tumor along the wall of the rectum in distal direction is less than $1 \mathrm{~cm}$, what was the background to revision of relations to distal resection line (1.5-2 cm instead of 5) [2-4]. More widespread use of sphincterosafing operations is made possible through the use of modern energy platforms for mobilization of removed preparation, the use of modern suturing devices and introduction of neoadjuvant radiotherapy, which reduce the size of the primary tumor [5-9].

Performance of sphincterosafing operations is caused by desire of surgeons to keep the continuity of gastrointestinal tract, thereby improving the quality of patient's life. However, this technique carries the risk of some perioperative complications. Moreover, the preservation of rectal sphincter doesn't always provide satisfactory functional results.

In this literature review we would like to elaborate on the pathogenetic aspects and techniques of surgical correction of functional disorders in performing sphincterosafing operations for rectal cancer.
The functional anatomy of the rectum as the pathogenesis of low anterior resection syndrome

Functional results of sphincterosafing operations depend on a number of factors: the original function of anal sphincter and pelvic muscles, quality of surgery, technology of anastomosis, patient's age, etc. [10]. In functional anatomy of the rectum there are two main components: the valve - a sphincter apparatus that creates resistance at the exit and the reservoir, whose main functions are volume and extensibility [11]. The valve consists of external and internal sphincter muscles (mm. sphincter ani externus, internus); the muscles that raises anus ( $m$. levator ani) and hemorrhoids. M. levator ani is formed by three muscles: puborectalis, pubococcygeal and iliococcygeal. The most important role in the functional relation is played by puborectalis muscle, forming the anorectal angle $\left(120^{\circ}\right)$. The flattening of this angle is the cause of incontinence. The external rectal sphincter is formed by striated muscles from slow fibers, which aren't prone to fatigue. It consists from three parts, forming a cuff around the middle and lower parts of the anal channel. The internal sphincter of the rectum is a continuation of the circular layer of the rectum. It provides $50 \%$ of resting pressure in the anal channel and is responsible for recto-anal inhibitory 
reflex. The sphincter apparatus responsible for formation of the zone of increased pressure in the anal channel and performs the holding function. The internal sphincter is in a state of constant tonic contraction, which is controlled by both external and internal nervous impulses [12]. The constant tonic activity of the external sphincter is maintained by nerve impulses from the S2 segment of the spinal cord. According to the literature, the internal sphincter provides 50$60 \%$ of the resting pressure in the anal channel, puborectalis loop and the external anal sphincter is $20-30 \%$, the hemorrhoidal "cushions" $15-20 \%$ of total control. Configuration of the anal channel plays an important role in maintaining function of output resistance [13].

The feeling of desires on defecation is performed by extraintestinal afferent neurons, which are activated by mechanoreceptors of the distal rectal parts. Stretching of the rectal wall causes a reflex relaxation internal and contraction of external sphincters. In the moment of internal sphincter relaxation, intestinal contents contact with the sensitive epithelium of the anal channel to determine the nature of intestinal contents. This continence is due to reflex contraction of the external sphincter. The reduction of the external sphincter can extend the period of retention of fecal masses and due to extensibility of the distal parts of colon walls to suspend the increasing of intrarectal pressure. By equalizing the pressure gradient, the further stretching of the rectal wall and stimulation of mechanoreceptors doesn't occur, sensation of urge to defecate passes. If the stretching of the rectum continues, reflex relaxation of the external sphincter occurs [14]. This phenomenon is called recto-anal inhibitory reflex (RAIR). Currently, it is believed that the RAIR is carried out by intramural reflex arcs [15].

Thus, the holding mechanism of intestinal contents is very complex. Causes of incontinence can be caused by disorders from the "valve", "tank" and other reasons:

- Valve: a defect of the sphincter, sphincter dysfunction, violation of the anal channel configuration: lack of the puborectalis function - a full incontinence; the deficit of the external anal sphincter - violation of strong-willed control; the deficit of internal anal sphincter - a violation of fine-tuning; deformation as a keyhole - leakage of feces.

- Tank: volume reduction after low anterior resection, radiotherapy, tumors, strictures, inflammation.

- Diarrhea: irritable bowel syndrome, radiation proctitis, etc.

The surgical injury of vegetative nerves also has negative impact on functional results in postoperative period [16]. Reflection of this is disappearance of RAIR [17,18].

Methods of surgical correction of functional disorders for patients with low rectal cancer

In the surgical treatment of rectal cancer the following types of surgical interventions with different types of reconstructive techniques are used: anterior resection with direct anastomosis, $\langle\mathrm{J}\rangle\rangle$ rectal reservoir, coloplastic rectal reservoir, "side to end" anastomosis; intersphincteric resection, abdominoperineal extirpation of the rectum (standard/ extralevatory). The formation of low anastomoses became widespread after introduction in practice of surgeons "direct" colo-anale anastomosis for A. Parks [18] and modern stitching machines. However, this technique is associated with various types of defecation disorders: frequent (up to 6 times per day) acts of defecation; prolonged and incomplete emptying of the bowel; the imperative urge to defecate; the phenomenon of anal incontinence. This syndrome is called "low anterior resection syndrome". The leading pathogenetic link of these functional disorders is a partial or complete loss of the rectal ampoule with violation of its reservoir function.

With the advent of interest in "low anterior resection syndrome" problem, in the middle of 1980's, the methods of prevention of this complication began to develop and various techniques of reservoirs were offered [20].

In 1986, F. Lasorthes and R. Parc, independently from each other, reported the first experience of formation of colonic reservoir in form of the latin letter "J". The efficiency of this method was proven in comparative study in a group of patients with «straight» anastomosis. According to results of the study was established that the minimum and maximum tolerated volume were higher in group 
of patients with reservoir anastomosis, the frequency of defecation in patients with $\mathrm{J}$ anastomosis was rarer (1-2 times daily) than in patients with «straight» anastomosis (3 or more times a day). Based on this data, the author concluded that stool frequency is inversely proportional to the maximum carrying capacity and it depends on the size of the reservoir construction [21]. However, in this work the extensibility of intestine down loading wasn't investigated.

In 1980, works on studying rectal distensibility was started. According to the researches, some authors (H. Suzuki, et al.), who studied this function in patients with «straight» anastomosis, the figures obtained remained fairly low in the next and late postoperative period [22-26].

When studying the adaptive functions of the colon wall of "J"-reservoir, data of most studies suggest that the rates of expansion was closer to the physiological norm about a year after the closure of preventive stoma [26-28]. The results of the work of many authors indicate that the frequency of anal incontinence in patients with a «straight» anastomosis is higher than in patients with reservoir anastomosis [29-31].

One of the problems of reservoir constructions was the problem of evacuation dysfunction. The first experience in formation of reservoirs shows, that $25-50 \%$ of patients had problems with bowel movement [26,32,33]. The reason for this was the size of the reservoir. At comparative assessment of evacuation abilities in patients with short $(5 \mathrm{~cm})$ and "long" $(10 \mathrm{~cm})$ reservoirs, it was proven that patients with shorter reservoir have fewer evacuation disorders [34]. Thus, reducing the size of the reservoir made it possible to achieve the best functional results.

One of the advantages of the "J"reservoir is the lower frequency of the lack anastomosis stitches, due to a better blood supply anastomosing site (while the wall of intestine down loading in the area of the «straight» anastomosis are more prone to ischemia), and filling "dead" space of pelvis of reservoir construction [35].

The disadvantage of the "J"-reservoir is a great size that creates problems with down loading, especially in narrow pelvis and the presence of distinct mesentery in sending down intestine [36,37].

In 1999, K. Z'graggen, et al. developed a new method of recreating the missing ampoule of the rectum. The researchers formed the one-loop reservoir by a longitudinal incision, and then cross sewing together of the reduced gut by continuous suture. Depending of the colon diameter, the length of the incision was 7-9 cm. According to C.J. Brown, he had the following advantages: compactness, ease of sending down in conditions of small pelvis and in patients with a short mesentery of the colon [30]. However, according to most studies, there was statistically significant differences in functional performance compared with "J" reservoir $[38,39]$.

Alternative version of the previously proposed structures is "side to end" anastomosis, first described by J.W. Baker in 1950 [40]. The advantages of "side to end" anastomosis are the technical simplicity of formation, reducing the frequency of symptoms of incontinence, the ability to use in narrow pelvis and reduce the risk of lack anastomosis stitches due to better blood supply of anastomosing sites. According to a meta-analysis of Cochrane, in five randomized studies comparing the results of forming "J"'--reservoir and "side to end" anastomosis, there were no statistically significant differences in relation to immediate and remote results.

In 2015 were published the results of prospective randomized study conducted in "State scientific center of Coloproctology after A.N. Ryzhikh" that compared the efficiency of "side to end" anastomosis and "straight" anastomosis according to functional results of physiological studies and quality of patient's life. The study included 80 patients (40 in the main and control groups). Based on the research results, the authors came to the conclusion that the functional results after low anterior resection with "side to end" anastomosis is better than "straight" in relation to severity of incontinence according Wexner's scale. This fact was also confirmed by the data of physiological studies: "side to end" anastomosis provides the best performance in terms of average constant urge to defecate and max- 
imum carrying capacity. According to the results of the FIQL questionnaire, the quality of patient's life with "side to end" anastomosis is better than those with «straight» [41].

\section{Conclusion}

Thus, according to most authors, the functional results of patients with "side to

\section{References}

1. Semionkin EI, Khubezov DA, Kulikov EP, et al. Analiz rezul'tatov perednej rezekcii prjamoj kishki. Rossijskiy medikobiologicheskiy vestnik imeni akademika I.P. Pavlova. 2013;21(2):107-10. (In Russ).

2. Mamedli ZZ. Kompleksnoe lechenie bol'nyh rakom sredne- i nizhneampulyarnogo otdelov pryamoj kishki [dissertation]. Moscow; 2011. Available from: http://medicaldiss.com/medicina/kompleksnoe-lecheniebolnyh-rakom-sredne-i-nizhneampulyarnogootdelov-pryamoy-kishki. Accessed: 25.11.2017. (In Russ).

3. Nevol'skih AA. Sovremennye podhody $k$ lecheniyu bol'nyh rezektabel'nym rakom pryamoj kishki [dissertation]. Moscow; 2011. Available from: https://search.rsl.ru/ru/record/ 01005009371. Accessed: 25.11.2017. (In Russ).

4. Williams NS, Dixon MF, Johnston D. Reappraisal of the $5 \mathrm{~cm}$ rule of distal excision for carcinoma of the rectum: a study of distal intramural spread and of patient survival. $\mathrm{Br} J$ Surg. 1983;70:150-4.

5. Barsukov YuA. Vozmozhnosti sfinkterosohranyayushchego lecheniya bol'nyh mestnorasprostranennym pervichno-neoperabel'nym rakom pryamoj kishki. Onkologicheskaya koloproktologiya. 2012;4:21-5. (In Russ).

6. Berdov BA. Nuzhna li luchevaya terapiya sovremennoj hirurgii rezektabel'nogo raka pryamoj kishki? Onkologicheskaya koloproktologiya. 2011;2:52-5. (In Russ).

7. Kulikov EP, Kaminsky YuD. Preoperative radiotherapy for low rectal cancers. Eurasian journal of Oncology. 2014; 3(3):490-1.

8. Kolyadich GI. Kombinirovannoe lechenie bol'nyh rakom pryamoj kishki s primeneniem predoperacionnoj krupnofrakcionnoj distancionnoj i sochetannoj luchevoj terapii [dissertation]. Minsk; 2006. Available from: end" anastomosis was better than in patients with "end to end" anastomosis. But currently remain many questions about this technique of surgery, and functional results don't always fully meet the demands of doctors and patients. These circumstances serve as the basis for further researches.

Authors have no conflict of interest to declare.

http://dep.nlb.by/jspui/handle/nlb/25219. Accessed: 25.11.2017. (In Russ).

9. Rasulov AO. Hirurgicheskaya taktika posle himioluchevoj terapii raka pryamoj kishki [dissertation]. Moscow; 2012. Available from: http://medical-diss.com/medicina/hirurgicheskaya-taktika-posle-himioluchevoy-terapiiraka-pryamoy-kishki. Accessed: 25.11.2017. (In Russ).

10. Laforest A, Bretagnol F, Mouazan $\mathrm{AS}$, et al. Functional disorders after rectal cancer resection: does a rehabilitation programme improve anal continence and quality of life? Colorectal Dis. 2012;4(10):1231-7.

11. Odaryuk TS, Vorob'ev GI, Shelygin YuA. Hirurgiya raka pryamoj kishki. Moscow: Dedalus; 2005. (In Russ).

12. Meunier P, Mollard P. Control of the internal anal sphincter (manometric study with human subjects). Pflugers Arch. 1977; 370(3):233-9.

13. Lestar B, Penninckx F, Kerremans $\mathrm{R}$. The composition of anal basal pressure. An in-vivo and in-vitro study in man. Int J Colorectal Dis. 1992;11(3):118-22.

14. Henry MM, Swash M, editors. Coloproctology and the Pelvic Floor. London: Butterworths; 1985.

15. Gowers WRG. The automatic action of the sphincter ani. Proceedings of the Royal Society. 1877;26:77-84.

16. Kim NK. Anatomic basis of sharp pelvic dissection for curative resection of rectal cancer. Yonsei Med J. 2005;46(6):737-49.

17. Fomenko OJu, Podmarenkova LF, Titov $\mathrm{AJu}$, et al. Rol' izmenenija parametrov rektoanal'nogo ingibitornogo refleksa $\mathrm{v}$ patogeneze anal'noj inkontinencii. Koloproktologiya. 2012;41(3):20-7. (In Russ).

18. Allgayer HD, Rohde W, Koch GF, et al. Prospective comparison of short- and 
long-term effects of pelvic floor exercise/ biofeedback training in patients with fecal incontinence after surgery plus irradiation versus surgery alone for colorectal cancer: clinical, functional and endoscopic/endosonographic findings. Scandinavian Journal of Gastroenterology. 2005;40(10):1168-75.

19. Parks AG. Transanal technique in low rectal anastomosis. Proceedings of the Royal Society. 1972;65:47-8.

20. Hallbook O, Pahlman L, Krog M. Randomized comparison of straight and colonic $\mathrm{J}$ pouch anastomosis after low anterior resection. Annals of Surgery. 1996;1:58-65.

21. Lazorthes F, Gamagami R, Chiotasso P, et al. Prospective, randomized study comparing clinical results between small and large colonic J-pouch following coloanal anastomosis. Dis Colon Rectum. 1997;12(40):1409-13.

22. Suzuki H, Motsumoto K, Amuno J, et al. Anorectal pressure and rectal compliance after low anterior resection. Br J Surg. 1980;67:655-7.

23. Pedersen IK, Hint K, Olsen J, et al. Anorectal function after low anterior resection for carcinoma. Ann Surg.1986;204:133-5.

24. Ho YH, Tan M, Seow-Choen F. Prospective randomized controlled study of clinical function and anorectal physiology after low anterior resection: comparison of straight and colonic $\mathrm{J}$ pouch anastomoses. $\mathrm{Br}$ J Surg. 1996; 7:78-80.

25. Nicholls RJ, Lubowski DZ, Donaldson DR. Comparison of colonic reservoir and straight colo-anal reconstruction after rectal excision. Br J Surg. 1988;75:318-20.

26. Ortiz H, De Miguel M, Armendariz $\mathrm{P}$, et al. Coloanal anastomosis: are functional results better with a pouch? Dis Colon Rectum. 1995;38:375-7.

27. Seow-Choen F, Goh HS. Prospective randomized trial comparing $\mathrm{J}$ colonic pouch-anai anastomosis and stright coloanal reconstruction. Br J Surg. 1995;82:608-10.

28. Williams MS, Seow-Choen F. Phisiological and functional outcome following ultra-low anterior resection with colon pouch-anal anastomosis. Br J Surg. 1998; 85:1029-35.
29. Park JG, Lee MR, Lim SB, et al. Colonic J-pouch anal astomosis after ultralow anterior resection with upper sphincter excision for low-lying rectal cancer. World $J$ Gastroenterol. 2005;17(11):2570-3.

30. Brown CJ, Fenech DS, McLeod RS. Reconstructive techniques after rectal resection for rectal cancer. Cochrane Database Syst Rev. 2008; P. 2.

31. Vorob'ev GI, Odaryuk TS, Car'kov $\mathrm{PV}$, et al. Blizhajshie i otdalennye rezul'taty sfinkterosohranyayushchih operacij s formirovaniem tolstokishechnogo «J» obraznogo rezervuara. Hirurgiya. 2000;6:41-7. (In Russ).

32. Pahlman L. Straight coloanal or colon-J-pouch anal reconstruction. Swiss Surg. 1997;6(3):255-8.

33. Fuchs KH, Sailer M, Kraemer M, et al. Coloanal J-pouch reconstruction following low rectal resection. Recent Results Cancer Res. 1998;146:87-94.

34. Hida J, Yasutomi M, Fujimoto K, et al. Functional outcome after low anterior resection with low anastomosis for rectal cancer using the colonic J-pouch. Prospective randomized study for determination of optimum pouch size. Dis Colon Rectum. 1996; 39(9):986-91.

35. Halbook O, Johansson K, Sjodahl R. Laser doppler blood flow measurement in rectal resection for carcinoma: comparision between the stright and colonic $\mathrm{J}$ pouch reconstruction. Br J Surg. 1996;83:398-2.

36. Ho YH, Yu S, Ang ES, et al. Small colonic J-pouch improves colonic retention of liquids-randomized, controlled trial with scintigraphy. Dis Colon Rectum. 2002; 45(1):76-82.

37. Lazorthes F, Chiotasso P, Gamagami RA, et al. Late clinical outcome in a randomized prospective comparison of colonic $\mathrm{J}$ pouch and straight coloanal anastomosis. Br J Surg. 1997;10:1449-51.

38. Pimentel JM, Duarte A, Gregorio C, et al. Transverse coloplasty pouch and colonic J-pouch for rectal cancer - a comparative study. Colorectal Dis. 2003;5(5):465-70.

39. Fazio VW, Zutshi M, Remzi FH, et al. A randomized multicenter trial to compare long-term functional outcome, quality of life, and complications of surgical procedures for 
low rectal cancers. Ann Surg. 2007; 246 (3):481-90.

40. Baker JW. Low end to side rectosigmoidal anastomosis; description of technic. Arch Surg. 1950;61(1):143-57.

41. Budtuev AS. Anastomoz bok $v$ konec pri nizkih perednih rezekciyah pryamoj kishki [dissertation]. Moscow; 2015. Available from: http://medical-diss.com/medicina/anastomoz-bok-v-konets-pri-nizkih-perednih-rezektsiyah-pryamoy-kishki. Accessed: 25.11.2017. (In Russ).

Kulikov E.P. - MD, Grand PhD, Professor, Head of Oncology Department, Ryazan State Medical University, Ryazan, Russian Federation. ORCID ID 0000-0003-4926-6646, Researcher ID U-3350-2017.

Kaminsky Yu. D. - MD, PhD, associate Professor of Oncology Department, Ryazan State Medical University, Ryazan, Russian Federation. SPIN 4546-0324, ORCID ID 0000-0001-8785-3687, Researcher ID U-3096-2017.

Klevcova S.V. - assistant of Oncology Department, Ryazan State Medical University, Ryazan, Russian Federation. ORCID 0000-0001-7708-1644, Researcher ID U-3095-2017.

E-mail: klevcovasveta1@rambler.ru 